\title{
On the Three-dimensional Teaching Model of Business English
}

\section{Peng Wang}

School of Foreign Studies, Shandong University of Finance and Economics, Jinan, Shandong, 250002

Abstract: With the rapid development of Chinese universities in recent years, business English has received extensive attention, especially the teaching and research of business English has received a lot of heated discussions. The teaching model of business English has become a hot topic in the education field. Based on the framework of constructing socialist theory, the three-dimensional teaching mode of business English is explored, and a new path is opened for the majority of business English teaching workers.

Keywords: Business English; Constructivism; Three-dimensional Teaching

To some extent, business English is a comprehensive subject, which includes business subject knowledge, English language knowledge, English skills, and business operations and skills. It can be seen that in the course of business English teaching, in addition to paying attention to the teaching of English itself, it is also necessary to train students how to use English for effective business communication, and English to deal with practical problems in international business flexibly. This is a student of business English. The necessary ability. This special teaching goal means that the teaching method of business English is bound to have a certain particularity, and it is precisely because this particularity has attracted a large number of business English teachers to study its teaching mode. This article focuses on the threedimensional business English Teaching mode.

\section{Features of three-dimensional teaching mode}

On August 28, 2001, domestic higher education introduced the concept of three-dimensionality for the first time. The concept was proposed because facing the current competition for talents, China needs to efficiently train innovative talents, but a flat paper medium teaching material and a courseware The CD-ROM teaching model is obviously unable to meet the needs of training innovative talents. Higher education must attach importance to the application of modern educational technology, give play to the role of modern educational technology, promote the organic integration of media and resources, form three-dimensional teaching materials, and develop three-dimensional teaching. . However, even if it is a three-dimensional textbook, what is involved is only one aspect of three-dimensional teaching. How to apply the three-dimensional teaching model in English teaching is still worth exploring.

The characteristics of the three-dimensional teaching model must first be analyzed from the connotation of specificity. Three-dimensional teaching includes multi-angle, multi-dimensional, multi-directional and multi-level. This teaching mode is completely different from the traditional instillation teaching mode. Under the teaching concept, the three-dimensional teaching model pays more attention to the integration of modern information technology and the requirements of modern society for talent training. Under the three-dimensional teaching mode, various teaching methods are combined, and the advantages of various teaching methods are selected to promote the effective combination of a series of information such as sound, picture, and video, and truly realize the integration of information dissemination. Under such a teaching model, it plays a prominent role in the development of open education and quality education. Students are conducive to forming new ideas in the learning process, realizing personalized learning,

Copyright (C) 2020 Peng Wang

doi: 10.18282/le.v9i7.1494

This is an open-access article distributed under the terms of the Creative Commons Attribution Non-Commercial License

(http://creativecommons.org/licenses/by-nc/4.0/), which permits unrestricted non-commercial use, distribution, and reproduction in any medium, provided the original work is properly cited. 
autonomous learning and interactive learning, and rich three-dimensional teaching information resources, The amount of knowledge is large, creating an ideal teaching environment for students, stimulating students' learning initiative, cultivating students' innovative spirit, and improving the overall teaching effect.

\section{Three-dimensional teaching of business English}

Applying the three-dimensional teaching model, in the process of teaching business English, teachers must adhere to modern teaching concepts, integrate modern information technology into the teaching process, and at the same time base on the needs of modern society for the training of business English talents, and instill the original teaching style The model is broken, the center of teaching is changed, the students' dominant position in the classroom is brought into play, and the three-dimensional teaching mode is implemented by using multimedia technology and Internet technology. The three-dimensional teaching mode of business English should create an ideal constructivist learning environment. In such a learning environment, students are truly regarded as the main body of learning, and students' needs are respected to the students' autonomy in the learning process. Teachers need to play the role of three-dimensional textbooks, and on the basis of completing the textbook content and teaching progress, guide students. They can use supporting listening materials, relevant text readings and the latest online materials to start teaching, so that the teaching of business English can be from the class Before, during and after class, students can fully grasp the cultural background, study skills and language skills involved in business English.

The application of three-dimensional teaching mode can enable teachers and students to complete business English teaching in a more realistic and ideal teaching environment. Teachers can use multimedia network technology to create a more ideal teaching situation for students, so that both parties can teach and communicate in a real language environment, thereby increasing the frequency and authenticity of teacher-student interaction. And this kind of teaching situation can also stimulate students' learning passion and motivation, and make students more truly touch the core of business English teaching. At the same time, teachers can also use modern communication media such as forums to form mutual encouragement and mutual supervision between students. Students can exchange knowledge and discuss opinions on such platforms, and teachers can also learn about students' knowledge And strengthen students' understanding of knowledge through evaluation. Three-dimensional teaching can also provide students with more powerful resource support, and provide students with a cognitive environment that can actively build knowledge. In addition, because of the particularity and professional complexity of business English, its teaching can not only stay in textbooks, but also go deep into life practice. The three-dimensional teaching can create a learning community through network resource sharing, and it is also beneficial for teachers to lead students to carry out case analysis and truly experience business negotiation activities.

The three-dimensional teaching model also provides convenience for students' learning, and diversified learning methods are conducive to the expansion of students' learning fields and learning horizons, and this is more in line with modern teaching concepts and drives students to learn independently and explore independently. At the same time, the three-dimensional teaching model can strengthen the process of English learning, so that business English teaching truly highlights the characteristics of language learning, and strengthens the distance and richness of learning. Multimedia technology is also more conducive to language construction for learners. The three-dimensional teaching model also makes business English teaching more in line with modern teaching concepts, which is conducive to the improvement of students' practical ability, can cultivate compound and application-oriented talents, and emphasizes studentcenteredness, so that students can better integrate into society in the future ,adapt to work.

\section{Concluding remarks}

my country's business English subject has appeared for a short time, and all aspects are in the stage of gradual exploration. On the whole, business English is still in the preliminary exploration period, and it is still a new subject. Business English itself has the subject characteristics of "language + specialty", which also leads to its complexity and comprehensiveness higher than many other subjects. In the face of such composite majors, it is necessary to be 
more scientific and rigorous when choosing a teaching model, taking into account the characteristics of its composite major, and achieving the teaching goals of business English more efficiently through innovative teaching models. The three-dimensional teaching model can better fit the teaching characteristics of business English, fundamentally improve the teaching quality of business English, and optimize the teaching efficiency of business English, which is a teaching model with great teaching value. At the same time, this teaching mode is more in line with the teaching goal of training comprehensive talents in business English.

\section{References}

1. Yan Chaoya. Research on the construction of three-dimensional practical teaching mode of business English [J]. Journal of Henan University of Science and Technology, 2020, 40(08): 65-70.

2. Mao Meina, Huang Bin. The integration of business English and English business_- the three-dimensional teaching model of business English from the perspective of CBI theory[J]. Journal of Chongqing Electronic Engineering Vocational College, 2018, 27(01): 120-123.

3. Zhang Yujia. Discuss the three-dimensional teaching mode of business English in colleges and universities[J]. Oriental Collection, 2018(01):141. 